\title{
Obituaries
}

Obituaries should be submitted by email to Jadene Doak at jadene.doak@springernature.com

All submitted obituaries should be 400 words maximum in length (apart from obituaries for past presidents of the BDA where the length should be 800 words).

Content of the obituary is down to the individual author, and the approval of the family should be given for the obituary prior to submission to the BDJ.

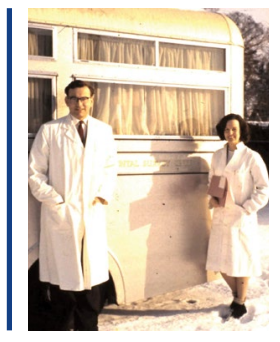

John Stacy Bulman

1933-2020

John Bulman was born in 1933 in

Twickenham. After education as a scholarship pupil at Christ's Hospital, from 1953 to 1955 , he was a National Serviceman in the Fighter Control Branch of the RAF. John then studied dentistry at the London Hospital, graduating in 1959. After a house post and with the encouragement of the dental sub-dean, Neil Livingstone Ward, he gained a Fulbright Travelling Scholarship to become a Postgraduate Fellow at the Forsyth Dental Infirmary for Children in Boston.

He returned as junior lecturer in conservation and children's dentistry, just as community and public health dentistry, including epidemiology, were advancing. The London and John played major roles in their development. Professor Geoffrey Slack agreed with the Nuffield Provincial Hospitals Trust to undertake a feasibility study for a survey of dental health and attitudes. John became the senior research fellow, beginning his renowned public health career in a custom-designed mobile examination trailer towed by a Land Rover. In November 1961, John married American Judith Connors who he met whilst at the Forsyth. They returned to England amidst the last London 'pea-souper' fog, and snow on the ground for four months. Judith became John's assistant. After five months in Salisbury, John went to Darlington, gathering data from contrasting northern and southern populations, acquiring a $\mathrm{PhD}$ in 1971. His report paved the way for the first national adult dental survey: John was responsible for the dental planning and organisation. He was also involved in one of the many 1970's fluoride dentifrice trials. He became Senior Lecturer in Community Dental Health.

John later transferred to the Eastman Dental Institute as reader and honorary consultant in dental public health and ran a renowned MSc course in DPH, for which he was a highly popular teacher. He was much in demand as a lecturer in the UK and abroad. John's expertise in statistics developed on the back of epidemiology was widely in demand to help other researchers. John Stacy Bulman died on 21 January 2020. Stanley Gelbier

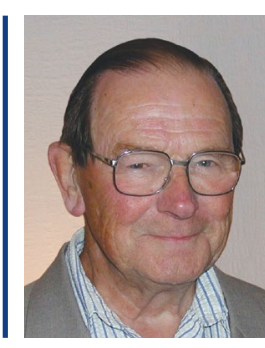

\section{Frank Darrah Rowe}

1923-2021

Frank Darrah Rowe died peacefully on 13 September 2021, two months before his $98^{\text {th }}$ birthday. He was educated at Merchant Taylors', Crosby and then graduated from Liverpool University in 1947 . He married Margaret Cheeseman on 3 January 1948, a partnership that was to last for 71 years. His primary interest was always orthodontics and he was employed at the Dental Hospital as an Assistant Orthodontist, before starting what would be a lifelong relationship with Lancashire Health Authority. At first, this was on a very part-time basis, and so he started his own private practice in Rodney Street, Liverpool, which was to flourish for 20 years. As the work for Lancashire increased, he used his considerable talents to mentor younger clinicians within the Health Authority, and was always known as a kind, patient and gentle man. His commitment to his patients was such that, when retirement approached and there was no one to replace him, he continued working until aged 75 in order to finish his waiting list. His expertise was so valued that in the 12 months before his death, he received a letter from a patient, thanking him for straightening her teeth over 40 years ago!

Frank had many interests outside of dentistry, including gardening, sailing, photography, ornithology and astronomy. He had a lifelong love of maps and books, and was heavily involved with his local church both as a preacher and Elder. He had a great affinity for young people and was a driving force in the children's work at the church. He helped organise an annual holiday club for children, only giving up due to coronavirus restrictions at age 95! His lifestyle was an active one, enjoying fell walking in the Lake District. He was a graceful skater and during the winter would use his lunch hour to skate on any canal that he thought would bear his weight - a practice viewed with consternation by family and dental staff alike! In his fifties, he took up skiing and rollerblading and enjoyed squash and badminton. He had a mischievous grin and a wicked sense of humour, but if there was one word to sum up Frank's life, it would be influential. He passed on his orthodontic expertise to many younger clinicians, and his faith to generations of young people by what he taught and said and did. A man greatly missed!

Philip Rowe 